\title{
Foreign Activities In Exclusive Economic Zone (EEZ) And Impact Towards Malaysia
}

\author{
Mohd Faudzi Zahari ${ }^{1}$, Noraini Zulkifli ${ }^{1 *}$ \\ Department of Strategic Studies, Faculty of Management and Defence Studies, National Defence University of Malaysia \\ Correspondence: noraini@upnm.edu.my \\ DOI: 10.29322/IJSRP.11.06.2021.p11432 \\ http://dx.doi.org/10.29322/IJSRP.11.06.2021.p11432
}

\begin{abstract}
As a maritime nation, Malaysia has developed its own maritime capabilities in order to safeguard its national interest over the sea especially in Exclusive economic zone (EEZ). Any activity that could threaten the strength of the economy can be regarded as betray national interests and actions must be taken to prevent it vociferously. South China Sea (SCS) is increasingly important not only in terms of defence strategy even in economic development of the country. It is used by the warships and merchant ships. This SCS is rich with natural resources such as oil and fishery. These natural resources will invite many foreign countries to come and do illegal activity in Malaysia's EEZ. Zone (EEZ) together with its impact towards Malaysian maritime security. This research was conducted to analyze the foreign activities in Malaysia's Economy Exclusive Zone (EEZ) together with its impact towards Malaysian maritime security. Where there are many foreign activities occurs in the waters of our country which indirectly affect the economy and national security. Therefore, the Security Forces should work together with the relevant agencies to safeguard the security of our country's waters from activities that could be harmful to our country's waters. This article has three objectives, namely 1) To identify foreign activities in Malaysia's EEZ; 2) To examine the impact of foreign activities to Malaysia's security. This article has used both primary and secondary data. Primary data was collected from structured interviews involving ten informants in various professional fields that are directly involved in maritime security in the Straits of Malacca. Secondary data was collected from literature reviews based on scientific publications, theses, journal articles, and online material, such as newspaper articles. Primary data was also obtained from professional respondents from abroad through electronic media such as email. The findings of this article are 1) Foreign activities in Malaysia EEZ can be divided into two types - traditional and nontraditional security issues; 2) The impact of foreign activities in EEZ is the national security of Malaysia became threated.
\end{abstract}

Keywords: Exclusive Economy Zone, Foreign Activities, Malaysia, Maritime Security, Maritime Safety.

\section{Introduction}

An Exclusive Economic Zone (EEZ) is a concept adopted at the Third United Nations Conference on the Law of the Sea (1982), whereby a coastal State assumes jurisdiction over the exploration and exploitation of marine resources in its adjacent section of the continental shelf, taken to be a band extending 200 miles from the shore. EEZ comprises an area which extends either from the coast or in federal systems from the seaward boundaries of the constituent states ( 3 to 12 nautical miles, in most cases) to 200 nautical miles (370 kilometers) off the coast. Within this area, nations claim and exercise sovereign rights and exclusive fishery management authority overall fish and all Continental Shelf fishery resources (Noraini \& Forbes 2016). The foreign activities in Malaysia's Exclusive Economic Zone (EEZ) consists of Piracy and Sea Robbery, Illegal, Unreported and Unregulated Fishing (IUU), Smuggling Activities, Illegal Discharging of Water, Human Trafficking, and Foreign Military Activities. Therefore, it is necessary to identify whether the foreign activities in Malaysia EEZ really a threat to national security and whether Malaysia has sufficient capabilities and policies or procedures in managing the exploitation of the sea, providing security at sea as well as maintaining good order at sea. Malaysia has made its declarations at the United Nations (UN) that Malaysia didn't want any foreign activity either military or non- 
ISSN 2250-3153

military in its EEZ (Geng 2012). Both activities will be undermining and threatening its security. According to the Exclusive Economic Act 1984, EEZ boundaries cover area beyond and adjacent with 200 nautical miles from the baseline where Malaysia has the sole right for exploitations overall its natural resources such as exploring and exploiting, conserving and managing natural resources (MMEA 2019). On top of that, Malaysia has jurisdiction over the establishment of artificial islands and installations, marine research and protection and preservation of the environment. According to The Exclusive Economic Act 1984, prohibited act or omission set out in the EEZ Act committed with the area or any EEZ facility is considered to take place in Malaysia and subject to criminal and civil jurisdiction of Malaysia courts. Map 1 below shown Malaysia EEZ and Maritime Zone for both theatre of Malaysia which includes Waters, Territorial Sea, Continental Shelf, Exclusive Economic Zones and Fisheries and includes the airspace over the Zone.
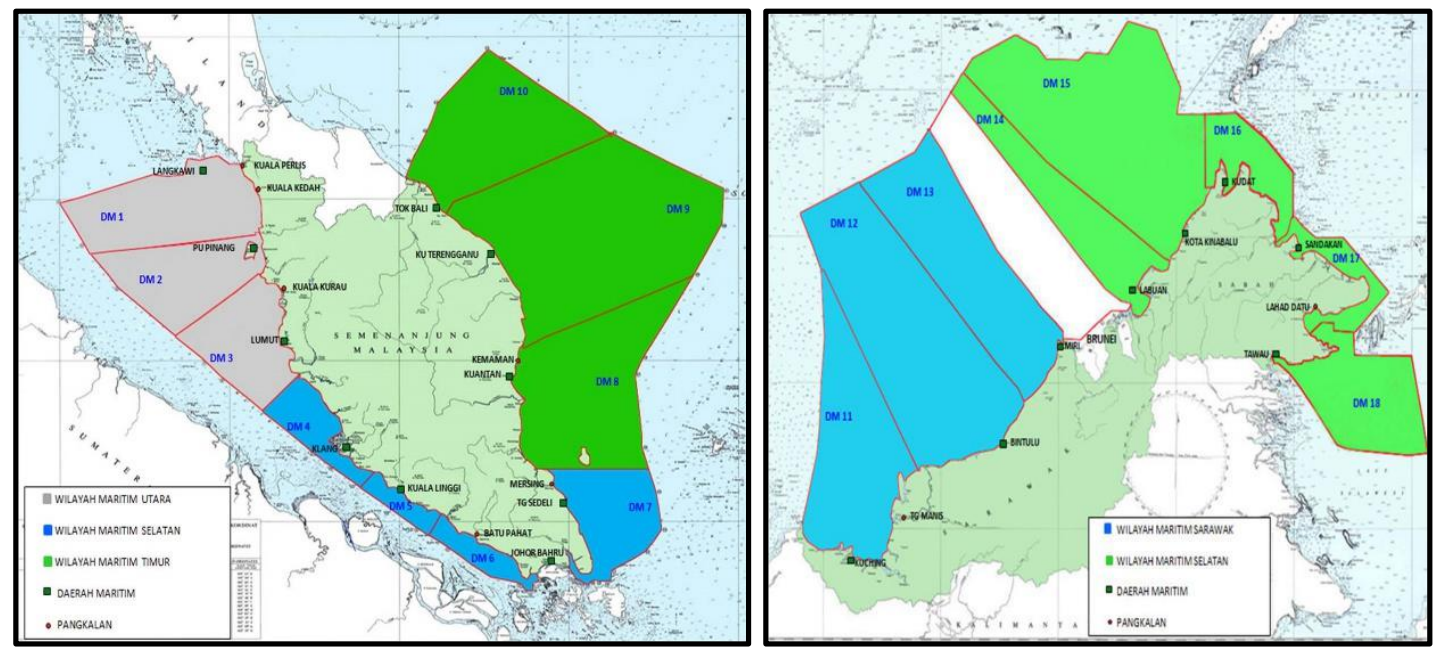

\section{Map 1: Malaysia EEZ and Maritime Zone}

Source: Malaysian Maritime Enforcement Agencies (2017)

https://www.mmea.gov.my/eng/index.php/en/citizens-and-public/36-malaysian-maritime-zone.

Malaysia EEZ in South China Sea (SCS) area is located at the East Coast of Peninsular and at the West Coast of Sabah and Sarawak. Malaysia has several claims towards SCS especially at the Spratly Islands. Malaysia claims 11 maritime features and managed to occupy 8 of them whilst Vietnam or Philippines occupied the balance of 3 features (Beckman \& Davenport 2010). Other countries that have influence over SCS are China, Brunei, Indonesia and Taiwan. The importance of the SCS cannot be denied. Within the boundaries of Malaysia EEZ, SCS also falls within Malaysia's offshore economic interests. One of the busiest international sea lanes in the world is in the SCS and part of Malaysia EEZ is included in the passage of the vessel. Most of the world merchant ship sails through SCS especially more than half of the world's oil tanker used or passing through it (UNTAD, 2016). SCS has become the main sea route for vital import and commodities export. Instantly, SCS has merged to become the hub of the industrial revolution of Asia (Noraini \& Forbes 2016). Malaysia is a maritime nation where it is situated at the crossroads of Southeast Asia. On the west, Malaysia controls the Straits of Malacca, important and strategic waterways between the east and to the East.

\section{Foreign Activities in Malaysia's EEZ}

Maritime trafficking routes closely follow commercial shipping lanes and the modalities and technologies employed by criminals are often more advanced than those used in legal trade (UNGA 2015). The vast expanses of ocean, the complexity of the maritime transportation system, the immense volume of cargo transferred at each port and the limited capacity for inspections of cargo creates an opportunity for criminals. Foreign Activities in Malaysia's EEZ is much related to criminal activities at sea in South East Asia. Many security risks in South East Asia were influence by the activities that happen around the neighboring country in the region. Most of the criminal activities included illegal fishing, smuggling of people, wildlife, smuggling of valuable goods such as cigarettes, weapons, alcohol and piracy. With the boundaries of 
200 nautical miles EEZ the increasing of overfishing or illegal fishing has become a security concern and has resulted in conflict between local and foreign fishers and the loss of revenue for affected local fishermen and their home countries (Anucha 2003).

Since September 11, 2001, terrorist attacks, the smuggling of weapons became a major concern for governments around the world especially Malaysia. These weapons can be easily transported illegally by sea. This weapon is used by pirates and other separatists or terrorists to conduct their operations. The use of sea lanes or shipping as a method of cargo moved is due to it because of the reliability of mass amounts of cargo move. Shipping and sea lanes offer anonymity for criminals where it can hide the criminal activity behind legitimate industry and it can also be appeared to be licit. According to the 2000 UN Convention against Transnational Organized Crime (UNTOC) criminal activities at sea which included piracy and armed robbery at sea, maritime terrorism and proliferation of Weapons of Mass Destruction (WMD), migrant smuggling and trafficking in persons, drug trafficking, and organized crime within the fishing industry and oil bunkering which challenge the public order of the oceans. These crimes occur in various maritime zones, especially in EEZ.

\section{i. $\quad$ Piracy and Sea Robbery Activities}

Piracy activities are one of the serious threats that occurring in Malaysian waters because of Malaysia is one of the maritime nation (Noraini 2018). This activity is considered a security threats because of the violence and danger imposed on boats, ships, and crews. Since the world had embarked to globalization, most of the international trade and goods transported by sea and this may expose them to criminal activities such as piracy and sea robbery. With the large volume of ships using SCS to transport the goods, it has provided the pirates the opportunity to a potential target with a high-payoff. In the present, approximately $45 \%$ of the whole world trade is using SCS as the means of transporting goods which involved nearly 70,000 merchants' vessels (UNCTAD 2019).

As stated in the International Maritime Bureau, Piracy and Armed Robbery against ships report from 2012 to 2016 there were only 12 pirate attacks in China and 7 in SCS compare during the same period where there were over 400 reported attacks in Indonesia, 65 in Malaysia, 33 in the Philippines and 34 in the Singapore Strait (ICC- IMB 2016). However, the pirates attack in Malaysia EEZ especially in SCS area saw a reduction of its activities as compared to the previous years. According to MMEA 2017 Annual Report, the piracy and sea robbery in Malaysia water has dropped below 3\% for the past nine years. In the year 2017, there are only four cases of piracies or sea robberies reported happen in Malaysia EEZ (MMEA 2018). The latest report by The ICC International Maritime Bureau for Piracy and Armed Robbery against Ships for the year 2018 stated that only two incidents happen in Malaysia (ICC- IMB 2018).

\begin{tabular}{|c|c|c|c|c|c|}
\hline \multirow{2}{*}{ Country } & \multicolumn{5}{|c|}{ Year } \\
\cline { 2 - 6 } & $\mathbf{2 0 1 4}$ & $\mathbf{2 0 1 5}$ & $\mathbf{2 0 1 6}$ & $\mathbf{2 0 1 7}$ & $\mathbf{2 0 1 8}$ \\
\hline Malaysia & 10 & 14 & - & 4 & 2 \\
\hline Indonesia & 47 & 54 & 24 & 19 & 25 \\
\hline Philippines & 2 & 4 & 3 & 13 & 3 \\
\hline Singapore Straits & 6 & 6 & - & 1 & - \\
\hline Thailand & - & 1 & - & - & - \\
\hline Vietnam & 1 & 13 & 3 & - & 2 \\
\hline
\end{tabular}

Table 1: Piracy and Armed Robbery Occurred in SEA

Source: ICC International Maritime Bureau (Piracy and Armed Robbery against Ship, 2014-2018) https://www.iccccs.org/reports/2018-Q2-IMB-Piracy-Report.pdf 
Table1 shows the statistic of piracy and armed robbery that occurred in South East Asia. Malaysia and Vietnam are among the lowest piracy and armed robbery at sea compared to other Southeast Asia countries. This is due to the aggressive action conducted by Malaysia government to deter this phenomenon. Indonesia has the most cases of piracy and armed robbery because of its geographical factor. According to Regional Cooperation Agreement on Combating Piracy and Armed Robbery against Ships in Asia (ReCAAP) annual report 2018, most of the piracy incidents in Asia occurred in the SCS and these were mainly theft onboard ships while sailing and anchoring.

\section{Chart 1: The Piracy and Armed Robbery against Ship Between 2009-2018}

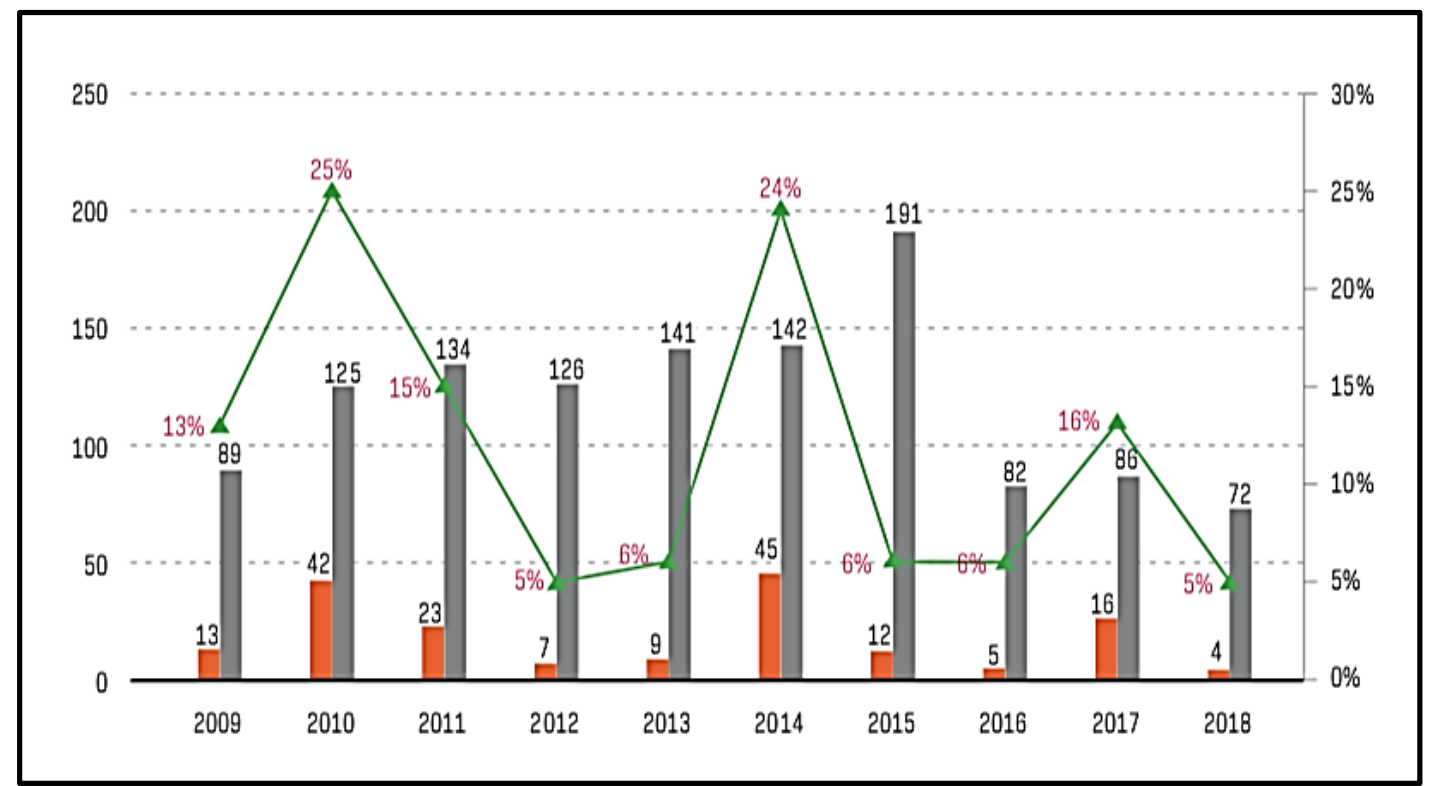

Source:

ReCAAP Annual Report (2018)

http://www.recaap.org/resources/ck/files/reports/annual/ReCAAP\%20ISC\%20Annual\%20Report\%202018.pdf

Chart 1 shown the statistic of piracy and armed robbery against ship at sea occurred in Asia for the year 2009 until 2018. In 2014 and 2015, most of the piracy incidents involved the hijacking of ships for theft of oil cargo. In 2017, of the 16 piracy incidents, 12 incidents occurred in the SCS. In 2018, all four piracy incidents occurred in the SCS. The chart also shown that the majority of the incidents reported in Asia are armed robbery against ships. 


\section{ii. $\quad$ Smuggling Activities}

Smuggling and human trafficking have happened long histories in Southeast Asia and the SCS is no exception where they are frequently regarded as extensions of historical trading arrangements between neighbours. It involves control items, cigarettes, drugs, alcohol and other valuable commodities. Traditional fishermen may be the parties that are carrying out the smuggling activities, but it was believed that the real masterminds are located onshore and keep themselves at arm's length from illegal activity (UNODC 2015). According to MMEA Annual Report 2017, MMEA managed to arrest 52 smuggling cases compared to 91 cases for the year 2016. Records show that the highest smuggling activities come from the control item categories such as cosmetic drug and medical drug with 13 cases, cigarette with 11 cases, petrol and diesel with 9 cases, and drug with one case. The activities of criminal drug trafficking and smuggling have certainly posed huge challenges to enforcement authorities (MMEA 2017). Malaysia, with its location as the transit hub of this region, has continued to become the hot spot of illegal drug smuggling. Located in the middle of South East Asia, Malaysia has made it a perfect location for these illegal activities.

\section{iii. Illegal, Unreported and Unregulated Fishing (IUU)}

The traditional fishermen faced huge losses due to illegal activities of foreign fishing boats and this could be seen from the significantly declining catches of the latter (Sim 2017). Malaysia fishing stock are fast depleting compared to its neighbouring countries across the Strait due to its developed fishing industry. According to the Fisheries Department, 980,000 tons of seafood worth up to RM6 billion is stolen annually by illegal fishing activities by foreign fishing vessels. Maritime enforcement coordination led by the Malaysian Maritime Enforcement Agency (MMEA) and supported by the Fisheries Department and the Marine Police Force, had succeeded in arresting 7,634 crew members of foreign fishing vessels since 2006 to February this year.

Additionally, the Department has concluded that an estimated 50 percent of the catch is landed outside Malaysia, in countries such as Thailand, Vietnam, and China (DoF 2013). IUU fishing activities in Malaysian fisheries waters include encroachment by foreign fishing vessels and unlicensed fishing by local fishing vessels. This illegal activity has resulted to negative and widespread environmental, social and economic consequences. Aside from its impact on the sustainability of target species, IUU fishing adversely affects associated and dependent species and the wider ecosystem (Zhou 2008). IUU fishing undermines international, regional, and national efforts to effectively conserve and manage fish stocks, the impacts of fishing and biodiversity. Ultimately IUU fishing can lead to the collapse of a fishery. The presence of illegal foreign fishing fleets undermines the security, safety and sovereignty of a State. Such presence will also intimidate the local fishers and jeopardize the harmonious fishing activities.

All fishing activities are governed by the Fisheries Act 1985 and its regulations and fisheries management policies. Management of fishery resources is complemented through the establishment of Marine Protected Areas (MPAs) such as marine parks and fisheries prohibited areas, installation of artificial reefs and prohibiting the use of destructive fishing methods and practices (DoF 2017). Malaysia manages her fisheries resources through an area zoning system. The system divides the areas into four fishing zones based on the distance from the shoreline namely; Zone A (0-5 nautical miles), Zone B (5-12 nautical miles), Zone C (12-30 nautical miles) and Zone C2 (30 nautical miles up to the EEZ). Fishing vessels of 40 Gross Registered Tonnage (GRT) and below operating traditional fishing gears are allowed to fish in any fishing zone. Vessels operating commercial fishing gears are allowed to fish in Zone B onwards depending on the tonnage of the vessels. Meanwhile, Figure 1 below show the management zones of fisheries in Malaysia.

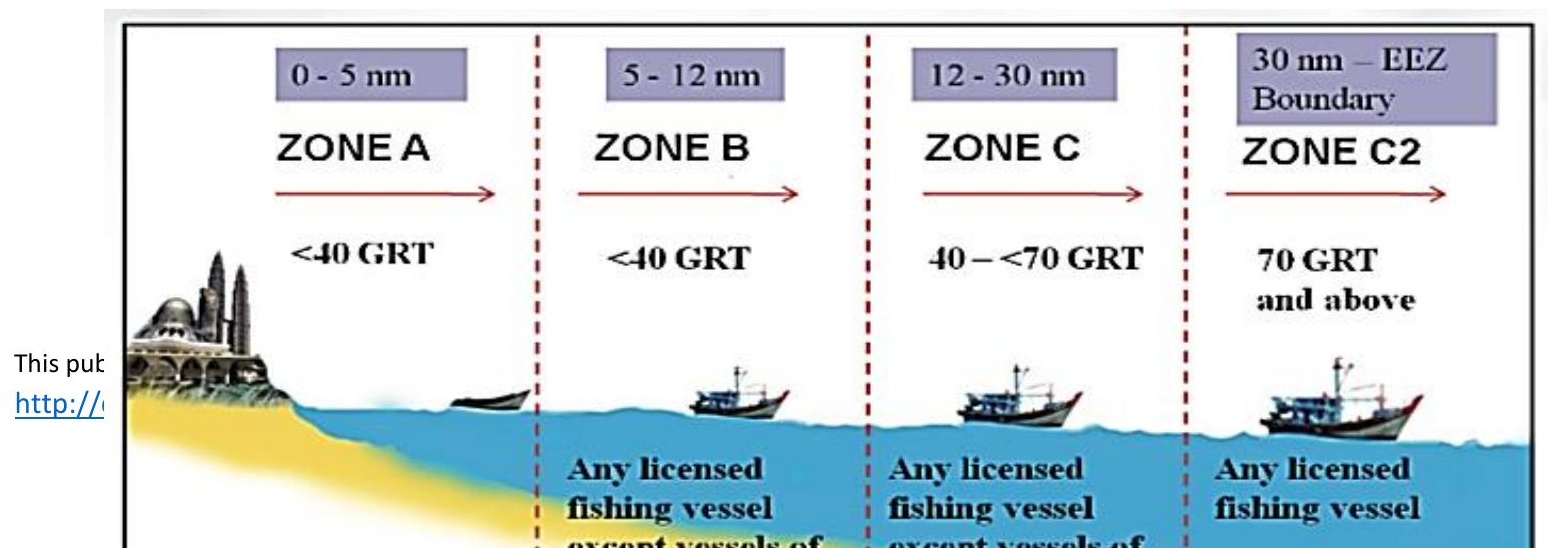


Figure 1: The Management Zone of Fisheries in Malaysia

Source: National Plan of Action for the Management of Fishing Capacity in Malaysia (2013)

https://www.dof.gov.my/dof2/resources/user_1/UploadFile/Penerbitan/Senarai\%20Penerbitan/NPOA.pdf.

\section{iv. Human Trafficking}

The issue of human trafficking and the smuggling of migrants are complex issues where it involved a wide range of stakeholders and actors across the trafficking chain. It also involved multiple modus operandi. Malaysia is a destination and also can be a transit country for women and children subjected to human trafficking activities (Suhana 2014). These activities were normally pertaining to forced prostitution and forced labor. In 2018, Malaysia was among the Tier 2 Watch List of the U.S Department of State's Trafficking in Persons Report (US Embassy 2018). These activities also will affect numerous security challenges to a state and its people and subsequently on its political, economic and social development.

A study by Reid (2012) pointed out that Malaysia is prone to human trafficking by being the host to a large migrant population, both legal and illegal. The majority of the victims were foreign workers who migrated willingly to Malaysia from Indonesia, Nepal, India, Thailand, China, the Philippines, Burma, Cambodia, Bangladesh, Pakistan and Vietnam in search of greater economic opportunities and some of whom subsequently encountered forced labour or debt bondage at the hands of their employers, employment agents or informal labour recruiters. Malaysia has imposed the Anti-Trafficking in Persons and Anti-Smuggling of Migrants Act 2007. These issues are taken care of and under the purview of the Ministry of Home Affairs which has established the Majlis Anti-Pemerdagangan Orang dan Anti-Penyeludupan Orang (MAPO) secretariat council in partnerships with numerous enforcement agencies and several local NGOs to curb this odious global crime. It is the country's main policy that guides on how to deal with this situation. The current government agencies that totally direct involved with these cases are the Royal Malaysia Police, Immigration Department, Department of Labour, Malaysian Maritime Enforcement Agency and Royal Malaysian Customs Department.

The Ministry of Home Affairs (2017) reported that 508 cases of human trafficking involving 398 cases (78.3\%) handled by the Royal Malaysia Police, 95 cases $(18.7 \%)$ by the Immigration Department, seven cases by the Department of Labor (1.4\%), six cases (1.2\%) by the Malaysian Maritime Enforcement Agency, and two cases (0.4\%) by the Royal Malaysian Customs Department. Table 2 below shows the statistics of cases for human trafficking between 2015 until 2017. Refers to the table there is some decrease amount of human trafficking during that period of time because of the highest law enforcement from the responsible agencies.

\section{v. Discharging in Ocean Waters}

Malaysian coastal waters, oil pollution is mainly caused by ships activities and tanker accidents (Law 1990). Vessel sourced pollution is one of the major sources of marine pollution and it encompasses accidental discharge of oil, intentional discharge of oil (like discharge from ballast tanks), chemicals and dumping. Although many new technologies and 
regulations are in place to overcome the problem of operational discharge, some ships still discharge their tanks, offload their toxic sludge and even solid waste in the relatively calm waters of its approaches to save costs of discharging them at the next port. This activity will have a negative impact on the marine environment as well as to the maritime community.

\section{vi. Smuggling of Wildlife}

Malaysia is a source and transit country for internationally trafficked wildlife products including ivory, rhino horn, pangolin, tigers and tiger parts, birds, reptiles and Testudines' (Dickson 2017). According to Krishnasamy (2016), Malaysia as a transit country plays a pivotal role in the international trafficking of ivory, Testudines' and pangolins. Malaysia is one of eight countries identified by the Convention on International Trade in Endangered Species of Wild Fauna and Flora (CITES) as being of "primary concern" and heavily implicated in the illegal trade in ivory. According to Wyler \& Sheikh (2008), there are three ways of how the process of wildlife trafficking being conducted. The first way is by hiding in secret compartments in luggage, shipping containers or clothing items. The second way is by wrongfully declared in the custom forms and trade permits as similar looking non-protected species, changing the declared item number, changing the value of the declared item, or declaring the wildlife as captive-bred and the third way is by smuggled in using stolen or altered trade permit to make seem that the contents are lawfully traded. In Malaysia, wildlife crime enforcement is divided into three regional wildlife agencies. Perhilitan will cover the whole Peninsular while Sarawak is the role of the Forests Department of Sarawak (FDS) and Sabah is under the jurisdiction of the Sabah Wildlife Department (SWD). Table 3 below is a table reflecting the wildlife cases investigated by these government agencies between 2012 until 2016.

\section{vii. Smuggling of Weapon and Other Explosive Device}

The increase in criminal cases in Malaysia is believed to have been originated from firearm smuggling. According to Lumpe et al (2000), firearms smuggling is the second-highest item that being smuggled after drugs. Smuggling of firearms into Malaysia is not a new phenomenon. Located in a strategic position of the maritime trading route, paved the reason for the increase of these smuggling activities. Capie (2002) mentioned that there are five factors that contributed to the firearms smuggling activities in South East Asia. Firstly, due to the internal conflict that has created a need for firearms through illegal sources by non-state actors. Secondly, this region has a history of previous conflicts in several countries where the firearms are continuing to prevail and easy to get. Thirdly, the geographical positioning of South East Asia has very long maritime space and continental borders which are very difficult to continuously patrol and monitor. Fourthly, some of the countries in this region cannot and at some stage have difficulties controlling their boundaries to stop the smuggling of weapons and Cross Border Crime (CBC) activities. Finally, despite the absence of conflict between countries in the region for more than two decades that has promulgated very encouraging regional development, nonetheless, suspicion and distrust continue to prevail among Southeast Asian countries.

\section{Foreign Military Activities in Malaysia EEZ}

According to UNCLOS 1982, any foreign military is not allowed to conduct any activities either exercise or maneuver especially when it involved with a weapon and explosive without the approved/consent from the coastal state. Sumarthy (2013) mentioned that most of the foreign military activities occurred in SCS especially in Sabah. According to the Minister of Prime Minister Department in the Parliament mentioned that there were 7 infringements with 16 navy assets by the People's Liberation Army Navy (PLAN) and China Maritime Surveillance (CMS) between 2013 until 2014 (Dewan Negara 2015). The Defence Minister of Malaysia in 2016 mentioned that the attendance of the China Coastal Guard ship at Beting Patinggi Ali at 84 nautical miles from Miri is still under control. Malaysia's approach over the past few years has been quieter and more low-profile (The Star 2014). Malaysia appears likely to continue its approach of realizing its interests using a range of diplomatic, legal, security, and economic measures while preserving its vital relationship with Beijing. Although Malaysia's approach to this issue is very low profile but the presence of both ship from MMEA and from Royal Malaysia Navy (RMN) is still continue in order to safeguard Malaysia water sovereignty. Air surveillance also will be continuously conducted by MMEA. On top of that, the presence of these ships also to test its operational readiness. Figure 2 below shows the China Coast Guard ship sited at Beting Patinggi Ali and closed surveillance by RMN. 
Smuggling of weapons and other explosives devices is the most challenging sea crime faced by the Malaysia government especially in EEZ. It is a major concern by the government now because of the new threats of terrorists or separatists. To name a few of these organizations such as ISIS, Free Acheh Movement, Abu Sayyaf, MILF and AL-Qaeda, these organizations need a weapon for their activities. For them to operate successfully, terrorist and separatist groups require modern weapons. The activities of these organizations in Malaysia have therefore intensified the illegal trade in arms and small weapons for the past several decades. In some parts of the region such as the southern Philippines, weapons are today readily available to terrorists, separatists, crime syndicates and pirates alike. These activities will lead to various serious crimes such as smuggling and drug trafficking, secret societies, gambling and vice activities, gangsterism, thuggish groups to be armed with firearms, armed robberies, assassinations and other organized criminal activities which are all unlawful. Several incidents that involved gun and weapon that being smuggled were the murder of Joe Fernandez, Lunas State Assemblyman, Kedah in 2000, the robbery of Southern Bank, Petaling Jaya in 2001 and a bomb blast at Movida Night Club, Puchong in 2016. These incidents indicated how serious the phenomena are. It has threatened the security of the people and the country, indirectly emerge as a stumbling block for development and contributes to increased crime.

\section{Foreign Activities impact towards Malaysia}

Malaysia has an extensive maritime boundary. Its EEZ is larger than its land area $(330,000 \mathrm{~km} 2$ land area vs. $450,000 \mathrm{~km} 2$ ). EEZ plays an important role in the nation's food and economic security. The fishing industry contributes between $1-2 \%$ to Malaysia's GDP. Fish is the primary source of protein for Malaysians. $60-70 \%$ of the nation's protein intake is derived from fish. Leal et al (2015) mentioned that IUU fishing reduces the sustainable management of marine ecosystems and fish stocks (unregulated catch reports and stock estimate), affects the livelihood of local fishermen, increases the black market for the illegal fish product, and negatively affects the fish industry market such as the wholesale or local distribution of the fish product. The negative impact of illegal fishing is enormous and has raised the concerns of governmental and non-governmental bodies, regional fisheries management organizations and all relevant stakeholders. If IUU fishing is not stopped or prevented, it will lead to negative impacts on the Malaysian fishing industry, such as the loss of valuable wild broodstocks, degradation of the marine ecosystem and over-exploitation of fishery resources. This will affect the economic and social livelihood of the fishers as well as the Malaysian fishing industry.

Piracy also poses a danger of threats to the safety of the ship will wider the economic impact of Malaysia where ships were afraid to sail using Malaysia waters. The Piracy reduces the ability of shipping countries to trade by sea for shipping. These threats also act indirectly as a threat to people's and country's security, indirectly as a stumbling block for development and contribute to increased crime. For the shipping industry, their costs are will incurred when they have to raise their workers' insurance premiums for a high-risk area. Other costs include installing preventative measures and protection on board, employing private security personnel, and as well as ransom payments if their worker has been kidnapped. In order to protect its water, Malaysia has to improve its budget. Enough assets and resources need to be made available to cover these huge areas, as well as areas that require particular attention such as the EEZs. Defence spending averaged around 1.5 percent of GDP, well below the regional average of 2.2 percent. Malaysia's defense budget does not include allocations for the Royal Malaysia Police (RMP) and the MMEA. Both civilian agencies are funded separately. For 2018, MMEA was allocated close to RM900 million with slightly more than half channeled towards the upgrading and procurement of new patrol boats. In spite of lower spending on defence, more funds have to be made by the government to ensure that MMEA, RMP and the RMN can purchase and upgrading of naval assets, which are sorely needed in especially to safeguard its territorial waters. By having a continuous patrol over the sea, the safety of navigation of vessels using Malaysia EEZ can be achieved. These elements are essential to ensure Malaysian waters are safe, secure and to preserve the marine environment. Safety passage is one of the crucial factors for vessels to travel in/out to another country.

Smuggling is an act of tax evasion which deprives the government of revenue for public expenditure. The taxes collected are normally affected by this phenomenon. The government will not collect enough revenue to fulfill its development projects. These include the construction of roads, bridges, schools, hospitals and other providers of essential services. Smuggling distracts the government from focusing on revenue collection. This is because a lot of resources are diverted towards dealing with the problem instead of collecting revenue. Goods that are smuggled into the country are often sold a lot cheaper than goods brought onto the market through the right procedures. Smuggling, therefore, deprives traders 
of free competition by creating undue competition with those who have paid taxes. Smuggling or sale of this product distorts market prices and creates unfair competition on the market.

A country can achieve better economic growth by developing its own industrial base. Smuggling low prices of the locally manufactured goods thus destroying the local products market. By providing the products at chipper prices which will disappoint and may also remove local producers from the market. This may result in the breakdown of domestic industries or leads local industries to collapse. The main economic problem triggered by smuggling activities is unemployed personnel. When there is unfair competition in the market, the industry will collapse and lead to many people losing their jobs. Many professionals, skilled and unskilled personnel remain jobless. Smuggling can cause insecurity especially when restricted goods like guns are smuggled. Such goods end up in the hands of a few people especially the terrorist who can use them to destabilize the security of the citizens of the country. Soyombo (2009) pointed out that this phenomenon will create a discouraging environment for foreign economic investors.

From the political point of view, Malaysia views transnational issues such as terrorism, piracy and organized crime as highly salient threats to its interests. Malaysia government will ensure that diplomacy is the main concern in order to ensure that the country feels completely secure. Seeing itself as a small, developing country, Malaysia is extremely sensitive about the infringement of its territorial water integrity and sovereignty. Malaysia places high strategic value on bilateral and multilateral defence diplomacy, which it calls "an important effort towards conflict prevention and escalation which could undermine peace and stability." Through such diplomacy, it seeks to shape the intentions of other states, build cooperation, gain access to resources such as technology and capital and help shape norms that can constrain potentially threatening actors. The Malaysian government will ensure that in protecting and advancing its autonomy and strategic interests, Malaysia places a high priority on bilateral and multilateral diplomacy. This approach can shape the intentions of other states, build cooperation, gain access to resources such as technology and capital, and help shape norms that can constrain potentially threatening actors. The National Defence Policy is also illustrates based on this approach.

Security threats to Malaysia are both traditional and non-traditional. The traditional threats come from geopolitics and external power relations, maritime boundary delimitation, securing SLOCs, military activities at sea and the implication of arms/naval build-up by navies in the region. Non-traditional threats in Malaysia can be divided into three categories (Noraini 2018). Firstly, is non -transnational crimes including smuggling, piracy, slave trading and illegal logging. Second is illegal seaborne including illegal immigration and criminals and terrorist movement across borders and environmental and lastly is economic issues, which includes accidental spill, illegal dumping or illegal fishing. Non-traditional security issues that are the focus of this report include piracy, terrorism, smuggling/human trafficking, illegal, unreported and unregulated fishing.

According to Mallia (2010), "Maritime Security is the understanding to include the preservation of territorial integrity and sovereignty and the maintenance of peace and order, so as to ensure the safety and protection of ships together with their passengers, crews and cargoes, and the protection of property and the environment". In other words, it is a freedom from or absence of some acts which could have a negative impact on the integrity and misfortune of waterway navigation or suppress the safety of persons, infrastructure, cargo, vessels which tend to legitimately exist, enraging its aging in legal transactions on, or transiting through territories and international waterways. Malaysia is highly dependent on maritime for transporting its goods abroad. Approximately $80 \%$ of Malaysia's export and import is transported using Sea Line of Communication (SLOC). The serious threats such as the risk of military clash, disturbance in transportation, political instability and any encroachment of its sovereignty will be a crucial effect on its economy. The security threats normally come from piracy, smuggling of small arms and drug. According to Tricia (2012), these activities can be connected to a bigger problem when it involved terrorism. Despite the fact that the arguments between maritime piracy and terrorism are debatable, there is some evidence of connections between these activities. It is believed that maritime piracy may be a useful tool as a way to raise funds for their activities.

Thousands of seafarers have been killed, injured, assaulted, became a hostage and threat from pirates has increased dramatically. They are on the frontline of the piracy problem. They have to live with the risk of attack. When ships are attacked by pirates, crews suffer the stress of being fired upon with guns and rocket-propelled grenades and those captured can be held hostage for months. Following a piracy attack, those involved can be seriously affected by post-traumatic stress. Indications are that pirates' treatment of the crew is worsening, with some seafarers having been held in solitary confinement 
and subjected to other cruelty. Malaysia is not the only state that has placed restrictions on foreign military activities in the EEZ. Malaysia is one of the countries that interpret the Treaty United Nations Convention on the Law of the Sea (UNCLOS) to prohibit any military activities and maneuvers in the EEZ without their prior permission. Military activities in the EEZ are a hot topic on the international agenda of states because they are becoming increasingly frequent for a number of reasons such as the rise in the size and quality of the navies of many nations, the technological advances that allow navies to exploit oceanic areas. Geng (2012) mentioned that other countries such as Thailand, Italy, Germany, the Netherlands, the United Kingdom and the United States perceive this provision as one permitting naval operations in the EEZ as an activity 'associated with the operation of ships' and more generally as protected within the scope of the freedom of navigation. Malaysia has pointed out that military activities in Malaysia EEZ prohibited without their permission.

Today, military activities by foreign nations in the EEZ of other nations are becoming more and more frequent for a number of reasons: the accelerating pace of globalization; the tremendous increase in world trade; the rise in the size and quality of the navies of many nations; and technological advances that allow navies to exploit oceanic areas. Along with this increase in military activity has come increasing contention over the scope of rights to military activities within the EEZ. These activities have security implications for Malaysia, especially when dealing with military activities. Unauthorized military activities are deemed not "peaceful" and prejudicial to Malaysia's security. According to Hamzah (2013), there are many reasons that Malaysia didn't agree on foreign military activities in Malaysia EEZ. In Malaysia's view, there is no law that prohibits a coastal state's jurisdiction over foreign military activities in the EEZ. Moreover, unauthorized foreign military activities can undermine a coastal state's security, particularly if they are non-peaceful in nature. In Malaysia's view, the 1982 Law of the Sea Convention is a treaty. Evidently, the provision of foreign military activities in the EEZ is a new concept. It is not customary international law, whereby states are obliged to obey, prescribe and enforce. Malaysia does not view the provision of military activities in the EEZ as being consistent with the principle of peaceful uses of the sea in UNCLOS. On the contrary, Malaysia views foreign military activities in its EEZ as not only undermining and threatening its security; it goes against the concept of peaceful uses of the sea, which it unconditionally supports.

Malaysia considers its declaration at the United Nations both as a defensive and protective mechanism. The declaration puts Malaysia on the right side of the law, signifying to the other members of the international community its objections to a provision in the Treaty to something which is not customary international law. Malaysia will never make a similar declaration against a clear-cut customary international provision. However, Malaysia has always maintained that a coastal state has primary responsibility and obligation to keep order at sea within its EEZ. The provision of unlawful military activities goes against the very grain of this primary obligation and undermines the rights of coastal states' jurisdiction in the Treaty with regard to military activities in the EEZ. Malaysia considers unauthorized military activities in the EEZ as unlawful and poses a threat against the territorial integrity and political independence of a sovereign state. (Article 2.4 of the UN Charter and Article 301 of the Treaty) In Malaysia's view, the phrase "internationally lawful uses of the sea" (UNCLOS Article 58 (3)) does not include military activities in the EEZ.

The Malaysian economy really relies on the sea. This area provides food sources to the locals and provides twothirds of Malaysian fishing. In addition, marine life and the beautiful coastline and islands on the west coast of Peninsular Malaysia contribute to the tourism industry. Any threats to this area will put Malaysia in danger and probably will jeopardize the Malaysian economy. The security of the Malaysia EEZ is paramount for Malaysia in order to boost its economy. These activities involve and affect various stakeholders such as several marine protected areas, tourist sites and resorts which are situated alongside the main ports and shipping lanes and actively generating income for the tourist destinations as well as for the nation. Due to this, any form of intrusion or interference would create fear which has the potential to not only endanger the environment of the marine but also the economy of the country. One of the causes that give an impact on foreign activity is sea pollution and marine life threats. Ships that embarking Malaysia through EEZ can intentional or accidental discharge such as oily-water, noxious liquids, sewage, garbage or contaminated ballast water are released into the marine environment. According to Thiel et al. (2013) in their research mentioned that the pollution caused by the dumped waste of the vessel has become increasingly widespread and raised a global concern especially when it's involved maritime environment pollution. Barnes (2002) pointed out that the illegal discharge shipborne garbage can cause threats and hazards to an abundance of marine life, hazards to human health, wildlife, organism invasion and depleting the marine ecosystem aesthetically. Carpenter and Macgill (2005) mentioned that the main cause that this phenomenon occurs is 
because of the ignorance of the international convention although shipborne garbage discharge at sea has been prohibited since 1973.

Another issued that causes a severe negative impact towards the marine environment is the illegal discharge of ballast water. Ballast water is defined as 'water (with its suspended matter) used to maintain the trim and stability of a vessel. This water is used to replaces cargo for example oil tankers. It also used for vessel control in order to balance the partially loaded container ships. While ballast water is necessary to maintain vessel safety and stability, it also facilitates the translocation of organisms to new areas. Joachimsthal et al. (2004) mentioned that ballast water contains materials of non-native, nuisance or exotic species that can cause severe ecological and economic damage to aquatic ecosystems. Hassan (2008) pointed out that Malaysia's coastal areas are rich by the diversity of natural, environmental and economic resources but the quality of marine life has deteriorated because of the pollution. This ballast water can cause a problem to ecological where this threat is the second greatest threat to marine life and furthermore extended to the human threat which can cause diseases and death. Ballast water is the principal pathway for the unintentional introduction of alien species. Picture 3.1 below shows how ballast water unintentional introduced/transported to another country.

\section{Conclusion}

The phenomenon of foreign activity in Malaysia EEZ is considered a serious threat especially to its economy, political and security. Malaysia is very consistent with the Treaty where it has absolute sovereign jurisdiction in its territorial sea and EEZ. It is crucial to safeguards its interest over the EEZ in order for the economy to prospers. Malaysia has the primary responsibility and obligation to keep order at sea within its territorial jurisdiction. Unauthorized or unlawful military activities goes against the very grain of this primary obligation and undermines the rights of coastal states' jurisdiction in UNCLOS with regard to military activities in the EEZ. The Malaysian government's approach to handling these foreign activities is by deterrence and diplomacy. Diplomacy requires international cooperation because those threats are primarily transnational. As mentioned, transnational maritime crime provides terrorist and guerrilla groups the means to move weapons and personnel, raise funds, and recruit new members. The government must have a strong political will to address and push on any move, plans, law enforcement and vision on securing Malaysia's sovereign rights. Ministries involve in the enforcement of the law of the seas must work together, avoiding any duplication of responsibility and execution of the development plan. The Ministry of Finance also should give some priority in the annual allocation of the operating and development budget in line with the national maritime policy of the nation. Execution and planning must be treated as a nation's strategic importance. The government should be very serious in developing the nation to be a maritime nation but not to emerge as a superpower. Maritime nation in Malaysia's context is more on an economic perspective and the security aspect of the nation. In this connection, the government has to develop adequate capability in terms of defence equipment, maritime-based industry infrastructure and maritime security-related system capability to cater for this effort.

\section{REFERENCES}

Anucha, C. (2003). Illegal Thai Fishing Robbed Indonesia off Billions of Catches and Catch. Southeast Asian Press Alliance, Vol 123, 15-25.

Barnes, D. K. A. (2002). Invasions by marine life on plastic debris. Nature, Vol 416 (6883): 808-809.

Carpenter, A., \& Macgill, S. M. (2005). The EU Directive on port reception facilities for ship-generated waste and cargo residues: The results of a second survey on the provision and uptake of facilities in North Sea ports. Marine Pollution Bulletin, 50(12): 1541-1547.

\section{Capie, D. (2002). Small Arms Productions and Transfers in Southeast Asia. Australia: Strategic and Defence} Studies Centre Australian National University. 32(3): 87-123.

\section{Dickson Chris (June 20, 2017) Criminal Justice response to Wildlife Crime in Malaysia.}

This publication is licensed under Creative Commons Attribution CC BY. 
https://www.unodc.org/documents/southeastasiaandpacific/Publications/201 7/Malaysia_Assessment_09.pdf.

New Straits Times (October 27, 2017). MMEA appreciative of RM900 million allocation. https://www.nst.com.my/news/nation/2017/10/295967/mmea-appreciative-rm900-million-allocation

Geng, J. (2012). The Legality of Foreign Military Activities in the Exclusive Economic Zone under UNCLOS Igitur. Utrecht Publishing \& Archiving Services. 12(6): 56-102.

Hamzah, B. (2013). Foreign military activities in the EEZ: preliminary views from the Safety of Navigation in East Asia, 13(7): 161-169.

Hassan, H. (2008). Ten years after Asian financial crisis 1998: Tourism growth in Malaysia. Research Bulletin of the Faculty of Economics and Management, 4(2): 51-56.

ICC International Maritime Bureau (July 8, 2016), Piracy and Armed Robbery against Ships. https://www.icc-ccs.org/reports/2016-Q2- IMB-Piracy-Report.pdf.

ICC International Maritime Bureau (July 8, 2019). https://www.icc-ccs.org/reports/2018-Q2-IMB-PiracyReport.pdf.

Jabatan Perikanan Malaysia (July 15, 2019). Landings of Marine Fish by State and Fishing Gear Group. https://www.dof.gov.my/dof2/resources/user_29/Documents/Perangkaan\%2 0Perikanan/2017\%20Jilid\%201/Jadual_Pendaratan.pdf

Joachimsthal, E. L. Ivanov, V. Tay, S.T.-L., \& Tay, J.-H. (2004). Bacteriological examination of ballast water in Singapore Harbour by flow cytometry with Fish. Marine Pollution Bulletin, 49(4): 334-43.

Krishnasamy. K (2016). Malaysia's Invisible Ivory Channel. https://www.traffic.org/publications/reports/malaysias-invisible-ivory-channel/

Law, A.T,V. Ravi. T \& Yeong C.H.(1990). Oil Pollution in the Coastal Waters off Port Dickson, Straits of Malacca, Pertika, 13(3): 381-387.

Leal, M. C., Pimentel, T., Ricardo, F., Rosa, R., \& Calado, R. (2015). Opinion: Seafood traceability: Current needs, available tools, and biotechnological challenges for origin certification. Trends in Biotechnology, 33(6): 331-336.

Department of Fishing. (September 20, 2019). Malaysia's National Plan of action to prevent, deter and eliminate illegal, unreported and unregulated fishing. https://www.dof.gov.my/dof2/resources/user_1/UploadFile/Penerbitan/Senarai\%20Penerbitan/Malaysia _NPOA_IUU.pdf.

Mallia, P. (2010). Migrant Smuggling by Sea: Combating a Current Threat to the Creation of a Cooperative Framework. 22(9): 34-98.

Maritime Security through

Malaysian Maritime Enforcement Agency. (2017). MMEA Annual Report. https://mmea.gov.my/eng/index.php/en/dokumen-penerbitan/82-laporan- tahunan-maritim-malaysia. 
Noraini Zulkifli \& Forbes, V,L. (2016). Japan and the South China Sea. Andalas Journal of International Studies. 5(1): 61- 83

Noraini Zulkifli. (2018). Straits of Malacca Maritime Strategic Interest towards Japan. International Journal of Research in Social Sciences. 8 (4), 240-259

Reid, J. A. (2017). Exploratory review of route-specific, gendered, and age-graded dynamics of exploitation: Applying life course theory to victimization in sex trafficking in North America. Aggression and Violent Behavior, 5(17), 257-271.

Review of Maritime Transport (2016). Retrieved on 7 July 2019 from https://unctad.org/en/PublicationsLibrary/rmt2016_en.pdf.

Robert C. Beckman and Tara Davenport, (2010). "CLCS Submissions and Claims in the South China Sea", The South China Sea Cooperation for Regional Security and Development, 12(7), 102-220.

Secretary-General of the United Nations. (July 14, 2019). "Oceans and the Law of the Sea," Report of the Secretary-General. https://documents-dds ny.un.org/doc/UNDOC/GEN/N15/269/73/pdf/N1526973.pdf?OpenElement.

Sim Bak Heng (July 9, 2019). Syndicates stealing fish from our waters. New Straits Times. https://www.pressreader.com/malaysia/new-straits- times/20171021/281715499855709.

Suhana \& Ali (2014). Government policy and the challenge of eradicating human trafficking in Malaysia. Malaysian Journal of Society and Space. 10 (6), 66- 74.

Sumathy, P. (2013). The rising turbulence in the South China Sea. http://www.mima.gov.my/phocadownloadpap/seaviews/73.Turbulence\%20i n\%20SCS(52013).pdf.

Soyombo, O. (2009). Sociology and Crime Control: That We May Live In Peace. An Inaugural Lecture Delivered at the University of Lagos, Akoka.

United Nations Office on Drugs and Crime . (2015). The Illegal Fishing and Organized Crime Neus. https://www.unodc.org/documents/congress/backgroundinformation/NGO/GIATOC Blackfish/Fishing_Crime.pdf.

The UNCLOS, Article 55. (March 3, 2019) https://www.un.org/Depts/los/convention_agreements/texts/inlos/inlos_e.pdf

The UNCLOS, Article 57. (March 3, 2019) https://www.un.org/Depts/los/convention_agreements/texts/inlos/inlos_e.pdf

The Star Online (March 6, 2013). A Look at Maritime Security in Malaysia. https://www.thestar.com.my/news/nation/2013/03/06/a-look-at-maritime- security-in-malaysia/. 
The Star Online (June 2, 2014). Quiet diplomacy the way to go. http://www.thestar.com.my/Opinion/Columnists/Mergawati/Profile/Articles/2014/06/02/Quietdiplomacy-the-way-to-go/.

The Star Online (Sept 28, 2018). Customs Foil Attempt to Smuggle in 435 Exotic Pets, Including Two Orang Utans, Via New Sea Route. https://www.thestar.com.my/news/nation/2018/09/22/435-exotic-petsincluding-two-orang-utans-smuggled-by-sea-seized-by-customs/.

The Star Online (July 18. 2019). Home Ministry announces another amnesty programme for illegals. https://www.thestar.com.my/news/nation/2019/07/18/home-ministry-announces-another-amnestyprogramme-for-illegals/.

Thiel, M., Hinojosa, I. A., Miranda, L. Pantoja, J. F. Rivadeneira, M. M., \& Vásquez, N. (2013). Anthropogenic marine debris in the coastal environment: A multi-year comparison between coastal waters and local shores. Marine Pollution Bulletin, 71(1-2): 307-316.

Tricia, A. Cronau (2012). Maritime Security, Malaysia's Persistent Problem. Air Command and Staff College. http://www.dtic.mil/dtic/tr/fulltext/u2/1022129.pdf.

United Nations: Ocean and the Law of the Sea (UNCLOS). (February 15, 2019) https://www.un.org/en/sections/issues-depth/oceans-and-law-sea/

United Nations Convention on the Law of the Sea (UNCLOS). July 15, 2019) https://www.un.org/depts/los/convention_agreements/texts/unclos/unclos_e.pdf.

United Nations Convention against Transnational Organized Crime and The Protocols Thereto. (June 20, 2019). https://www.unodc.org/documents/middleeastandnorthafrica/organised-crime/.

United Nations Conference on Trade and Development. (July 7, 2019) https://unctad.org/en/PublicationsLibrary/rmt2019_en.pdf.

US Embassy in Malaysia (2018). Trafficking in Persons Report. https://my.usembassy.gov/ourrelationship/official- reports/report-trafficking-in-persons-062918/.

Wyler, L. S. \& Sheikh, P. A. (2008). International illegal trade in wildlife: Threats and U.S. policy. http://fpc.state.gov/documents/organization/102621.pdf.

Zhou, S., Griffiths, S.P. (2008). Sustainability assessment for fishing effects (SAFE): a new quantitative ecological risk assessment method and its application to elasmobranch bycatch in an Australian trawl fishery. Fisheries Research 91:56-68. 